\title{
Funding of Agricultural Research and Development in Ghana: The Case of Council for Scientific and Industrial Research (CSIR)
}

\author{
Roland Asare*, George Owusu Essegbey \\ CSIR-Science and Technology Policy Research Institute, Accra, Ghana \\ Email: "rnyasare@yahoo.com,nryasare@csir-stepri.org
}

Received 14 April 2016; accepted 23 May 2016; published 26 May 2016

Copyright (C) 2016 by authors and Scientific Research Publishing Inc.

This work is licensed under the Creative Commons Attribution International License (CC BY). http://creativecommons.org/licenses/by/4.0/

(c) (i) Open Access

\section{Abstract}

Agricultural Research and Development (R\&D) investments contribute greatly to economic growth, agricultural development and poverty reduction in developing countries. This paper examines the financial investment and expenditure trends in agricultural R\&D in Ghana with emphasis on the Council for Scientific and Industrial Research (CSIR) and the implication for the policies driving agricultural research in Ghana. Data from Agricultural Science \& Technology Indicator (ASTI) and in-depth studies on agricultural R\&D in Ghana were used. Purposive sampling was used to gather data in thirteen agricultural research institutes and five public universities in Ghana. Through questionnaire administration, data were collected and analyzed using descriptive statistics. The study revealed that, total public agricultural R\&D expenditure had increased by 59 per cent from 42.5 million (2005 PPP) dollars in 2000 to 67.7 million (2005 PPP) dollars in 2011 and with an average expenditure of 54.1 million (2005 PPP) dollars per year. The total expenditure by CSIR constitutes about 50 per cent of the total agricultural research expenditure in Ghana. The study however, showed a drastic decline in capital investments from 6.7 per cent in 2000 to 0.1 per cent in 2011 of the total government funding with operational cost following similar declining pattern. Still, when considering the totality of funding including salaries and wages, government support is the main source of funding for agricultural $R \& D$ in Ghana ( 85 per cent) with donors (7.3 per cent), sale of goods and services (6.7 per cent) and others serving as complementary sources. Though there have been considerable government investments in agricultural R\&D in CSIR over the period, impact on operational and research activities has been minimal as the chunk of it went into payment of salaries and wages. The fundamental challenge is funding the very important operational and research activities which lead to technology development and innovation. Increasing commercialization of research technologies and government investment in agricultural R\&D in Ghana, are recommended to address this investment challenge.

\footnotetext{
${ }^{*}$ Corresponding author.
} 


\section{Keywords}

\section{Agricultural R\&D, Public R\&D Expenditure, Purchasing Power Parity (PPP)}

\section{Introduction}

Rising food prices are globally compounding the challenges of hunger and poverty [1]. In the next fifty years agricultural production needs to be increased more than ever before in spite of the fixed amounts of arable land, dwindling water resources, population increase, decreasing soil fertility and the impact of climate change [2]-[4]. These challenges have placed high demand for new technologies to achieve increased agricultural productivity, food security and the post-2015 development goals related to poverty and hunger as well as nutrition and health. This objective can be achieved through investment in agricultural R\&D [5] [6].

Considering that agriculture holds the key to Africa's development, the African Union in 2003 came up with the Maputo Declaration which enjoins member states to increase agricultural investments to at least 10 per cent of their national budgets [7]. The goal was to increase annual agricultural productivity by 6 per cent over the next 20 years. To this end, it called for an investment into the agricultural sector with the chunk of the investments going into agricultural research, extension and education systems; and institutional reforms that will increase the efficiency and effectiveness of the spending on research and extension [7]. Agriculture plays a central role in promoting growth and poverty reduction in the Ghanaian economy. A central objective in Ghana Shared Growth and Development Agenda (GSGDA) is for the agricultural sector to "play a critical role in the transformation of the country's economy" [4] [8]. This emphasis on agriculture is still underscored with the global adoption of the Sustainable Development Goals (SDGs) in September 2015. Goal 2 of the SDGs aims to end hunger, achieve food security, improve nutrition and promote sustainable agriculture. Promoting sustainable agriculture must be knowledge-based and must ensure resource availability for the generation and application of knowledge. Agriculture sector continues to be the mainstay of the economy of Ghana and also an avenue for job creation especially in the rural areas. The sector has enjoyed sustained growth over the past few years recording growth rates of 6 per cent and 6.1 per cent in 2008 and 2009 respectively. In Ghana, the agricultural sector performance has direct link with other sectors of the economy. It contributed over 22 per cent of Gross Domestic Product (GDP) in 2014 and this amounted to 23,640 million Ghana Cedis (Institute of Social Statistical and Economic Research) [9].

Agricultural research has generated several kinds of technology with the high potential for impact in sub Saharan Africa, though the direct impact on farmers' productivity, livelihood and quality of life has been brought into question [10].

As an investment, it has been shown again and again to deliver high returns, in terms of both financial benefits [11] and broader livelihood impacts [12]. Similarly, Chen and Demurger 2002, FAO 2001 cited in [13] reported that investment and technology are the prerequisite for agricultural growth and development. Increased government spending on agriculture has been linked to the ability of east and south Asian countries to achieving the Millennium Development Goals [14]. The importance and the gains made by the agricultural sector over the years could be partly attributed to the existence of strong agricultural Research and Development offering technical support to the sector and upon which the future of agriculture in Africa depends.

The interest in the study of investments in agricultural Research and Development (R\&D) in Ghana stems from evidence which supports the fact that all over the world, investments in Agricultural R\&D have immensely enhanced agricultural productivity [15] [16] leading to higher incomes, lower poverty levels and greater food security among others, albeit with a long time lag. Also analyzing public agriculture expenditure highlights the importance of the composition of agricultural spending, as different types of agricultural spending can affect agricultural growth differently [17] [18]. Of all types of agricultural expenditures, spending on agricultural research and development is crucial to growth in agriculture. Despite its numerous potential, agricultural research is in crisis on the African continent with its capacity constrained by a combination of government neglect and externally imposed policy conditionality. This has resulted in a significant loss of key personnel and the undermining of locally based contextually relevant research efforts [19].

Funding and investments in agricultural R\&D are some of the critical issues affecting research activities in 
many developing countries including Ghana. Over the years, serious concern has been raised about the increasing decline in funding of actual agricultural R\&D activities in Ghana in spite of increase in public agricultural R\&D spending in the past decade. At the same time, sources of funding to support agricultural R\&D have been a major challenge for many countries in Africa [20].

It is against this background, that this paper presents the long term trends in public agricultural R\&D expenditure and sources of investment in Ghana. The overall objective of this paper is to identify factors underlying public agricultural expenditure and investments in Ghana from 2000-2011 with the focus on the Council for Scientific and Industrial Research (CSIR), the main R\&D organization in Ghana. The paper identifies intensity ratio and volatility trends for the period 2000 to 2011, highlights constraints of agriculture R\&D investment and makes recommendations for agriculture policy in Ghana.

\subsection{National Agricultural Research System (NARS) and the CSIR}

Agricultural research is fundamental to enhancing Ghana's agricultural productivity. To this end, Ghana has created a National Agricultural Research System (NARS) that spans research institutes, tertiary educational institutions, and other organizations. How effective the NARS has been in enhancing agricultural practices and productivity in Ghana is a fundamental question of concern to all stakeholders, including policymakers, farmers, researchers, and development workers. Ghana's main agency for agricultural R\&D is the Council for Scientific and Industrial Research (CSIR) and its 13 research institutes, of which 10 are engaged in agricultural and related research activities.

The CSIR provides the main research institutional framework for agricultural technology development and innovation. Other agricultural research institutions outside of the CSIR also exist including the Cocoa Research Institute of Ghana (CRIG), Biotechnology Nuclear Agricultural Research Institute (BNARI) and the Marine Fisheries Research Division (MFRD). This is complemented by research work in tertiary educational institutions.

\subsection{Council for Scientific and Industrial Research}

The Council for Scientific and Industrial Research (CSIR) is operating fairly autonomously under the Ministry of Environment, Science, Technology, and Innovation (MESTI). CSIR is the largest and main R\&D agency in Ghana which was established in 1968. The Council for Scientific and Industrial Research Act, 1996, Act 521— the law that created CSIR_categorically stipulates 14 functions for the institution, including:

- To pursue the implementation of government policies on scientific research and development.

- To encourage in the national interest, scientific and industrial research of importance for the development of agriculture, health, medicine, environment, technology, and other service sectors, and to this end, to encourage close linkages with the productive sectors of the economy [21].

The 10 CSIR institutes involved in agricultural or related research activities are: Animal Research Institute (ARI), Crops Research Institute (CRI), Soil Research Institute (SRI), Oil Palm Research Institute (OPRI), Food Research Institute (FRI), Forestry Research Institute of Ghana (FORIG), Plant Genetic Resources Research Institute (PGRRI), Savanna Agricultural Research Institute (SARI), Water Research Institute (WRI) and Science and Technology Policy Research Institute (STEPRI). Both STEPRI and WRI have mandates that are broader than agricultural research.

The CSIR over the years have made efforts to address its institutional mandate. Whilst there are question marks on the extent to which it has impacted on agriculture in Ghana in terms of technological transformation, there is evidence that there are positive contributions to agricultural development with the release of agricultural technologies over the years developed by CSIR researchers. A desk review and scientist survey conducted by CSIR-STEPRI and IFPRI in 2010 showed that, out of the 109 agricultural technologies generated and identified in Ghana, 91 per cent of them were developed by CSIR researchers and the remaining by the Universities [22]. Though this contribution from CSIR may not have met the expectation of policy makers and other stakeholders, it however shows the important role CSIR plays in the development of the agricultural sector through research and development and transfer of technologies to farmers.

\section{Methodology}

The analysis in this paper is based on comprehensive data sets derived from primary surveys conducted in Gha- 
na by the Agricultural Science \& Technology Indicator (ASTI) programme of the International Food Policy Research Institute with CSIR-STEPRI in 2009 and 2012. Additionally, there was an in-depth study of Agricultural R\&D capacities in Ghana conducted by CSIR-STEPRI in collaboration with International Food Policy Research Institute (IFPRI) and West and Central African Council for Agricultural Research \& Development (CORAF/ WECARD) in 2013. To facilitate cross country comparisons, all financial data from the ASTI survey have been converted to 2005 purchasing power parity (PPP) prices using the World Bank's, World Development Indicators [23]. Purposive sampling was used to sample 13 agricultural research institutes and five higher educational institutions across the country for the ASTI survey, while 10 agricultural research institutes of CSIR were purposively selected for the in-depth study in Ghana. Through interview and questionnaire administration, primary data on agricultural R\&D human resource capacity, financial resources and expenditures, research infrastructure and resources and outputs was collected and supplemented by secondary data from institutes' annual reports for analysis.

\section{Results and Discussion}

\subsection{Trends in Agricultural R\&D 2000-2011}

The contribution of agricultural researchers to national development through agricultural $R \& D$ is very crucial as this is reflected in agricultural output such as the release of new technologies as well as agricultural productivity in general. From 2000 to 2011, the number of Full-Time Equivalent (FTE) researchers in Ghana steadily increased, from 470 in 2000 to 607 in 2011 representing an increase of about 30 per cent for the period, though there was a slight decline in 2002 (Figure 1). CSIR is the dominant contributor to the total number of agricultural researchers in Ghana contributing about 68 per cent while the higher educational institutions and other nonCSIR government research institutions are complementary contributors. Beyond CSIR, 57 departments of agriculture of public higher educational institutions and two non-CSIR government institutes-CRIG and MFRD were involved in the study. This also highlights the importance of CSIR in the NARS in Ghana and therefore the performance of CSIR to some extent has a direct link with the performance of the agricultural sector.

The study revealed that, the trend in public agricultural R\&D expenditure as shown in Figure 2 has increased from 42.5 million (2005 PPP) dollars in 2000 to 67.7 million (2005 PPP) dollars in 2011 representing an increase of 59 per cent over the period and an average expenditure of 54.1 million (2005 PPP) dollars per year. Within this period the expenditure showed a fluctuating pattern with the peak expenditures of 57.7 million (2005 PPP) dollars and 73.1 million (2005 PPP) dollars recorded in 2004 and 2009 respectively and a lowest of 41.0 million dollars in 2001 and 2006 (Figure 2). For CSIR, the pattern is not different with Agricultural R\&D

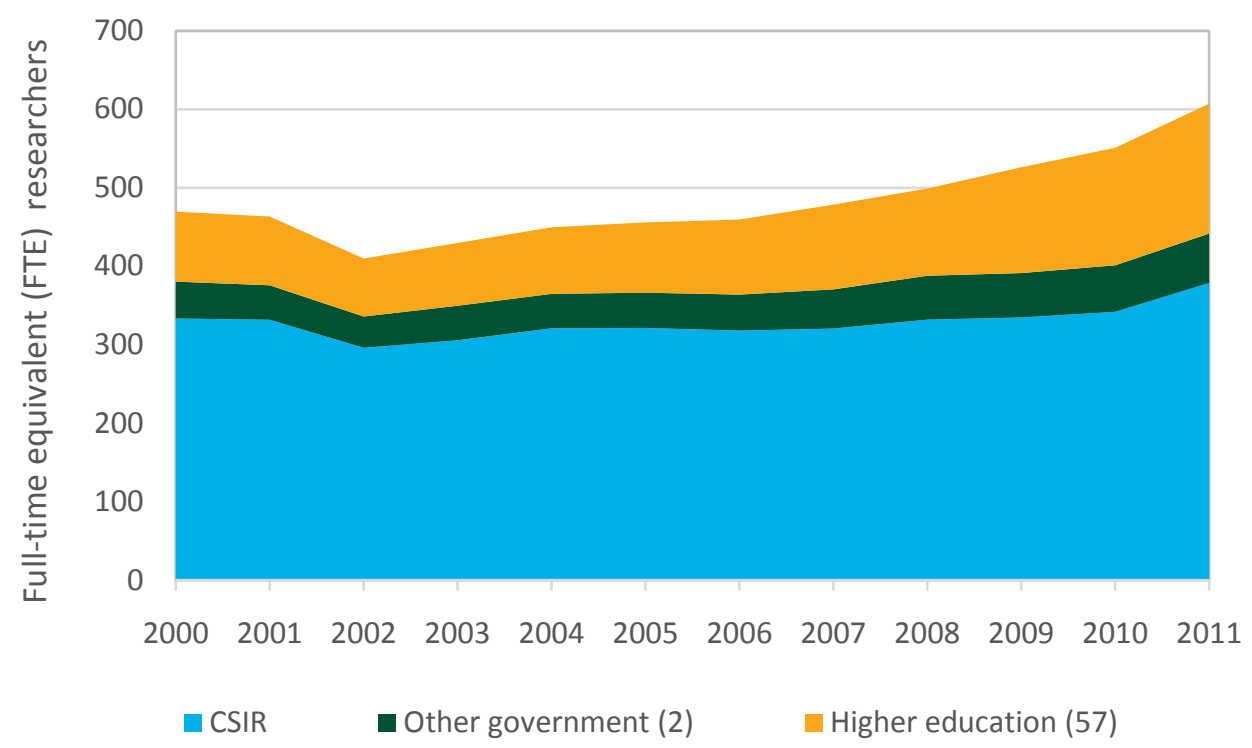

Figure 1. FTE agricultural researchers by institutional category, 2000-2011. Source: Compiled by authors from the ASTI/IFPRI database. 


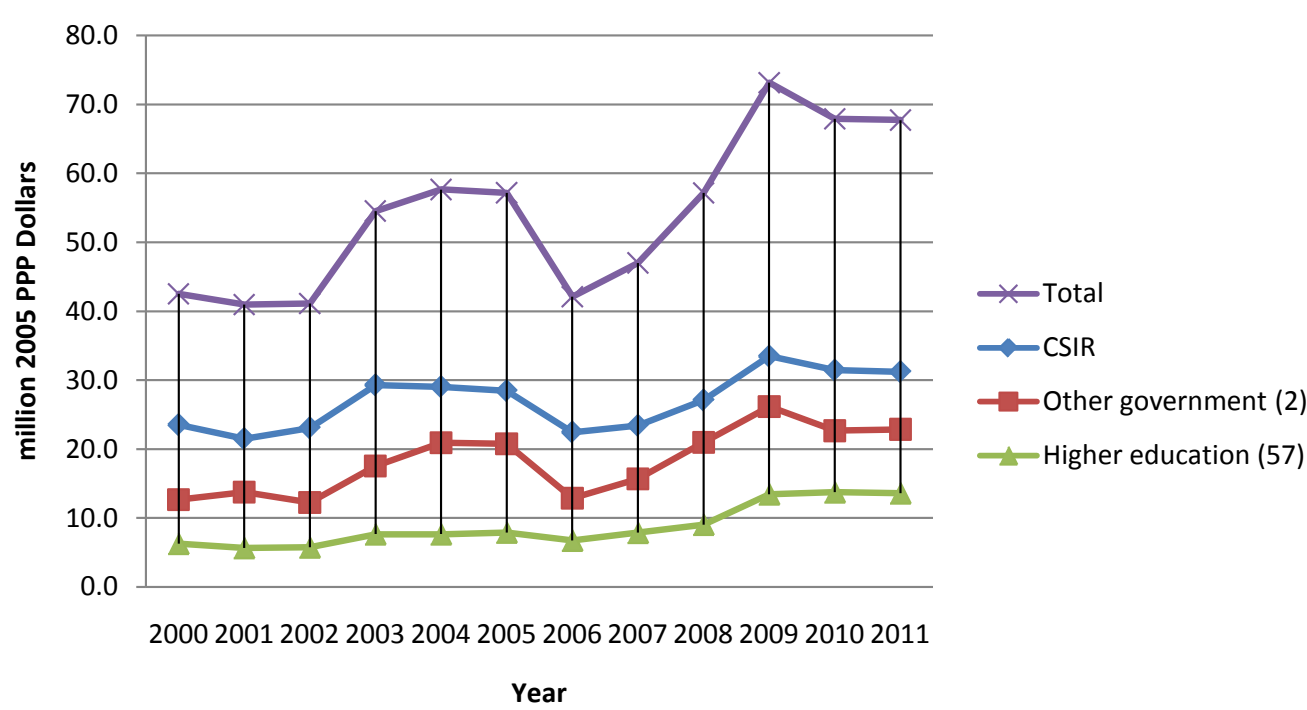

Figure 2. Public agricultural R\&D expenditure by institutional categories 2000-2011. Source: Compiled by authors from the ASTI/IFPRI database.

expenditure of 23.5 million (2005 PPP) dollars in 2000 increasing to 31.2 million (2005 PPP) dollars in 2011. The trend also shows uneven pattern with peaks of 29.3 and 33.5 million (2005 PPP) dollars recorded in 2004 and 2009 respectively. This fluctuating pattern can be attributed to uneven investment into agricultural R\&D especially from donors and development banks that are important source of funding for agricultural R\&D activities in Ghana.

\subsection{CSIR Agricultural R\&D Expenditure by Cost Category}

The contribution of CSIR to the total agricultural R\&D expenditure is quite significant and this constitutes about 50 per cent of the total for the country, showing an increase of 42 per cent over the period considering government-funded expenditures. The expenditure for CSIR by cost category follows similar pattern to that of the total agricultural R\&D expenditure. On the average, salary of staff accounted for 78 per cent of the total agricultural $\mathrm{R} \& \mathrm{D}$ expenditure in CSIR, while operating and program cost and capital investments accounted for 20 per cent and 2 per cent respectively. The study showed a drastic decline in capital investments from an already low 6.7 per cent in 2000 to 0.1 per cent in 2011 (Figure 3). This phenomenon indicates the priority of the government as far as agricultural R\&D in Ghana is concerned. The government seems to be interested in only getting researchers paid without the provision of requisite financial resources to work and the infrastructure for R\&D which are of utmost importance. The drastic decline in capital investment means that there is virtually no investment in infrastructural development. Consequently, development, maintenance, rehabilitation and operation of infrastructure such as laboratories, offices and equipment for research and development have become a major challenge confronting the institutes. A recent study of Ghana's science equipment policy underscored the deficiencies in Ghana's scientific laboratory infrastructure including CSIR, and called for upgrading laboratories and equipment [24]. These findings and recommendations could not have come at a better time than now that there is serious dwindling in government budgetary allocation for capital investment to CSIR. The onus now is on the institutes to look for funds from other sources to address this shortfall in funds from the central government.

\subsection{CSIR Agricultural R\&D Investment Sources}

The funding for agricultural R\&D in Ghana are obtained from various sources but mainly government, donors, development banks' loans, sale of goods and services and other sources. Figure 4 illustrates the point that government funding is dominant in CSIR agricultural R\&D investment sources accounting for over 80 per cent of the total funding averagely between 2009 and 2011. However, for the period 2009-2011 the total investment declined from 33.92 million to 30.682 million (2005 PPP) dollars. Government continues to be the main source of funding for agricultural R\&D at CSIR contributing on the average of 84 per cent of the total funding while 


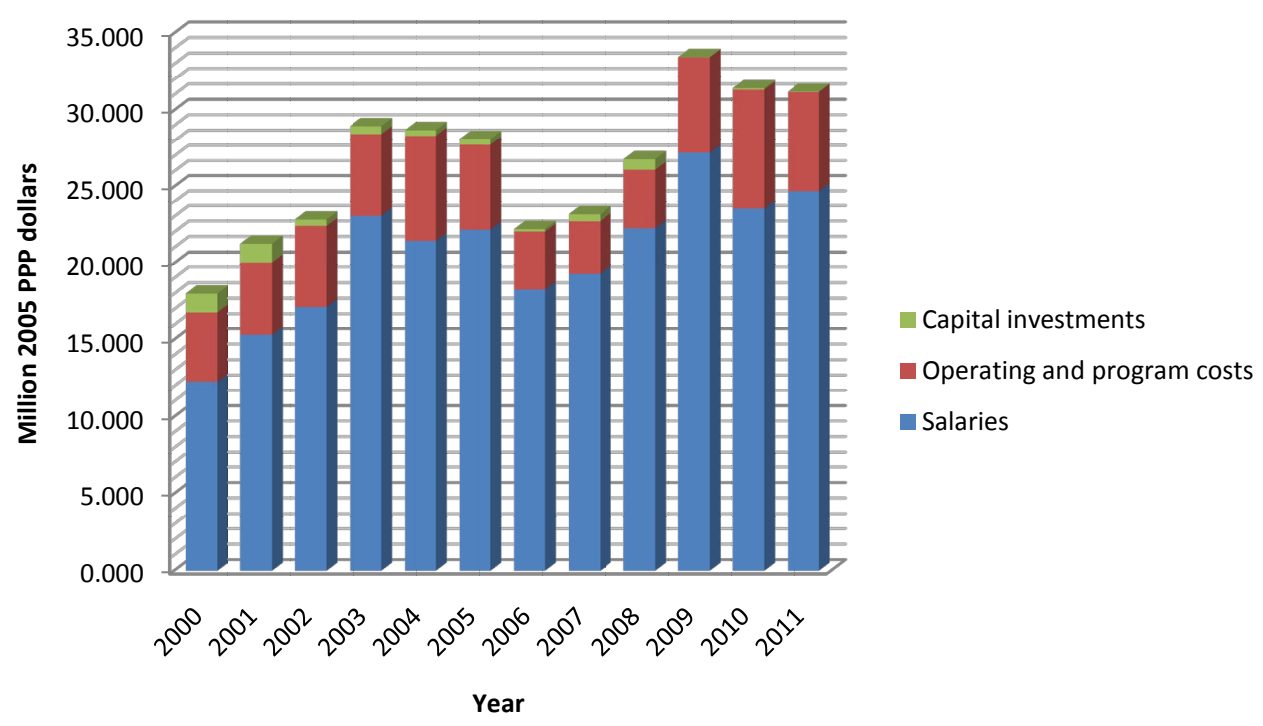

Figure 3. CSIR agricultural R\&D expenditure by cost category 2000-2011. Source: Compiled by authors from the ASTI/IFPRI database.

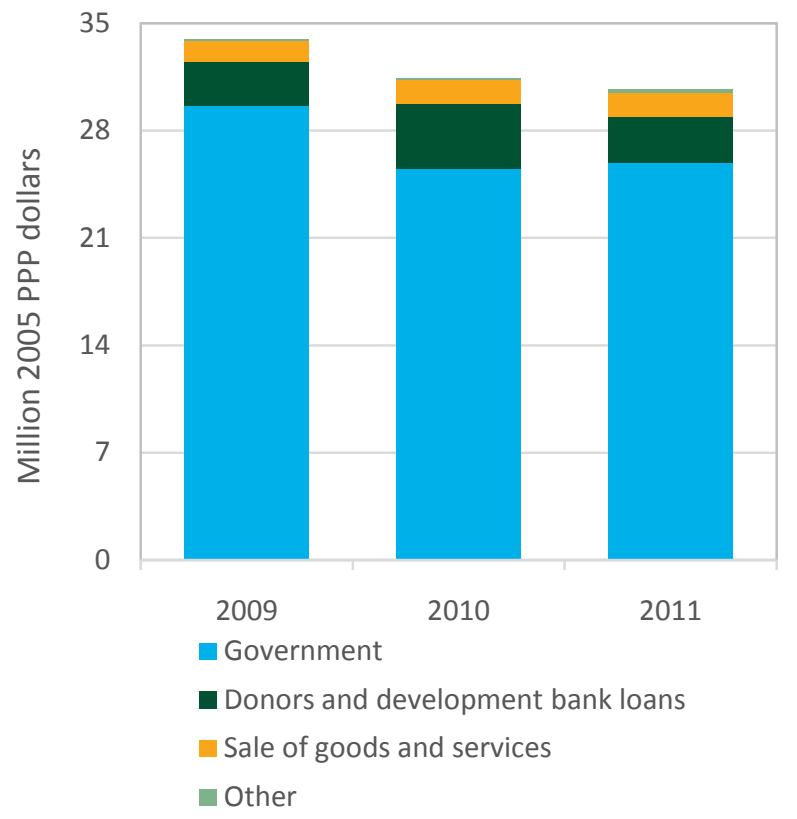

Figure 4. CSIR funding sources 2009-2011. Source: Compiled by authors from the ASTI/IFPRI database.

support from donors and development bank loans 10.5 per cent, sale of goods and services 5 per cent and other sources account for the 0.5 per cent (Figure 4). Conventionally the government being the dominant source of funding to CSIR institutes has been the norm considering the fact that the organization is a public entity that needs to be maintained with public funding. The process of sourcing funding from government by public institutions begins with presenting and defending budgets to the government through the Ministry of Finance. The approved budget after defense is much less than the requested funding. For instance, in the year 2010, only 41 per cent of the total budget presented by CSIR was actually approved [25]. As the payment of salaries and wages is the government priority over the others, anytime there is a cut in the presented budgets, it does not affect Personnel Emolument (PE) as a result approved budget for personnel compensation is close to the actual disbursement. 
Further analysis of the three core cost components of the agriculture R\&D expenditure by CSIR for 20092012 vis a vis funds from government source has shown differential disparities between budgeted and actually disbursed funds. While there is not marked difference between budgeted and disbursed government funding for Personnel Emolument (PE), in 2011 and 2012 there was a shortfall of 2 and 5 per cent respectively (Figure 5).

Unlike PE for staff which has seen a gradual increase from 2009 to 2012 with no marked difference between budgeted and actually disburse amount, funds for recurrent expenditure for the operation activities of the institutes have experienced a continuous decline since 2010 to 2012 from 2.5 to 1.6 million Ghana Cedis (See Figure 6). Funding for recurrent expenditure also showed a similar pattern as PE except that in 2012 there was a shortfall of 25 per cent between the budgeted and disbursed funds (Figure 6). The recurrent component is where the operational budget for the institutes lies. Any shortfall definitely affects R\&D activities. However, the study has shown that, government is aware that various donor agencies and funding sources fill the gaps in funding resources for CSIR. Currently the actual disbursement of the recurrent component of government subvention is less than the approved.

The trend in development expenditure (capital investment) showed a very different pattern with a much larger difference between the approved and disbursed budget. From 2009 to 2012, actual disbursement of the approved budget was only 15 per cent. This share would have been lower if 2011 were excluded. Apart from 2011 when 80 per cent of budgeted were actually disbursed to CSIR, for all the other years no fund was disbursed from the government to cover this expenditure (Figure 7). The trend has serious implications on the core agricultural research activities as infrastructure and modern equipment to support research is likely to be affected due to limited

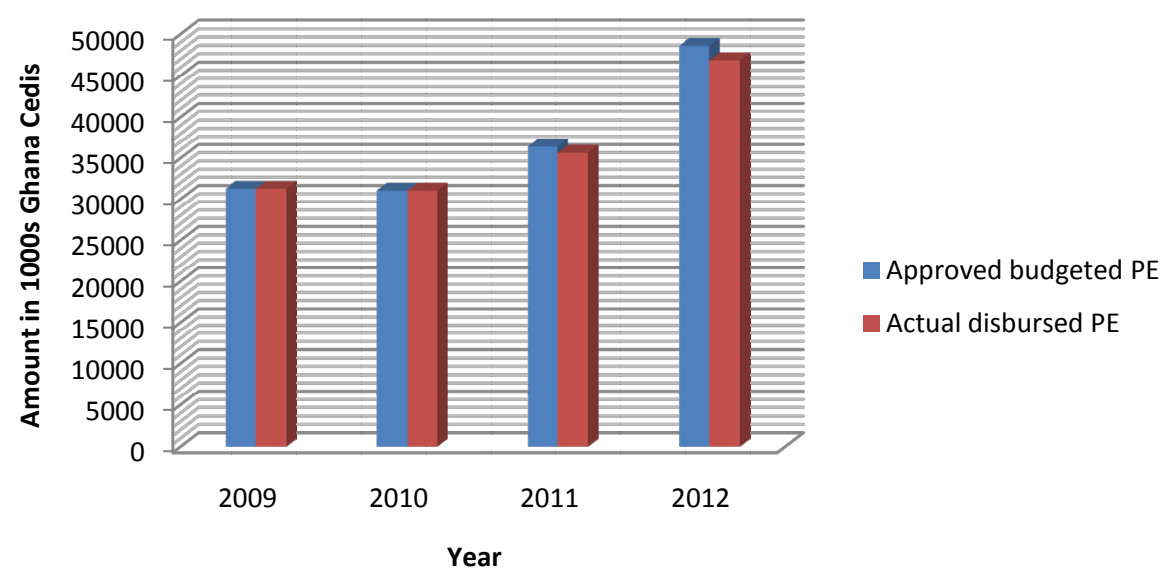

Figure 5. Government funding allocated to Personnel Emolument. Source: Compiled by authors from ASTI/IFPRI-CORAF/WECARD-STEPRI survey data.

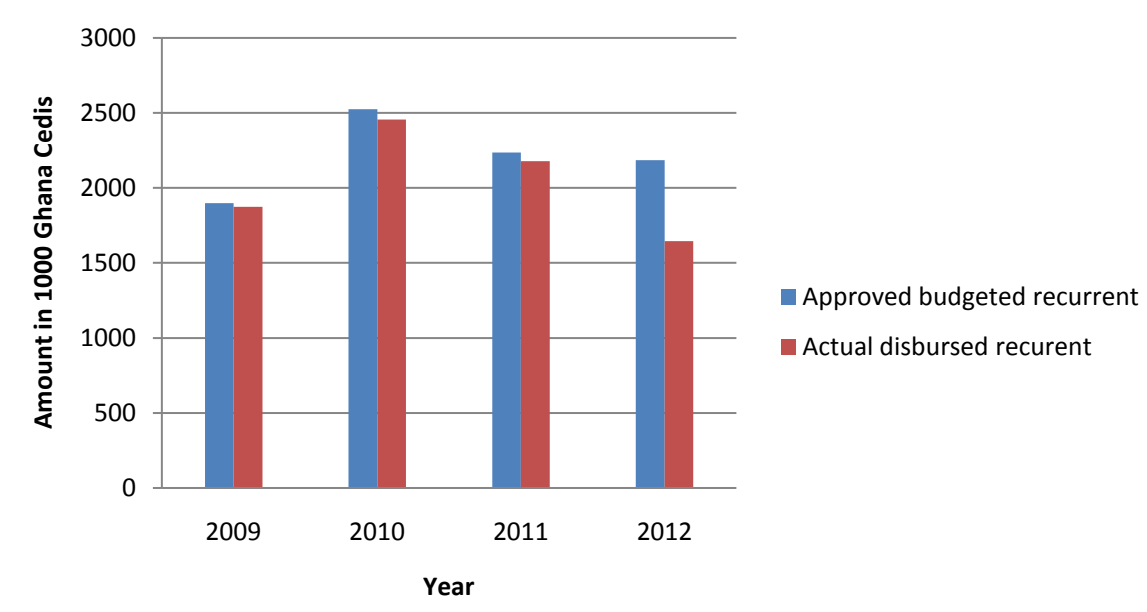

Figure 6. Government allocation to recurrent/operation expenditure. Source: Compiled by authors from ASTI/IFPRI-CORAF/WECARD-STEPRI survey data. 


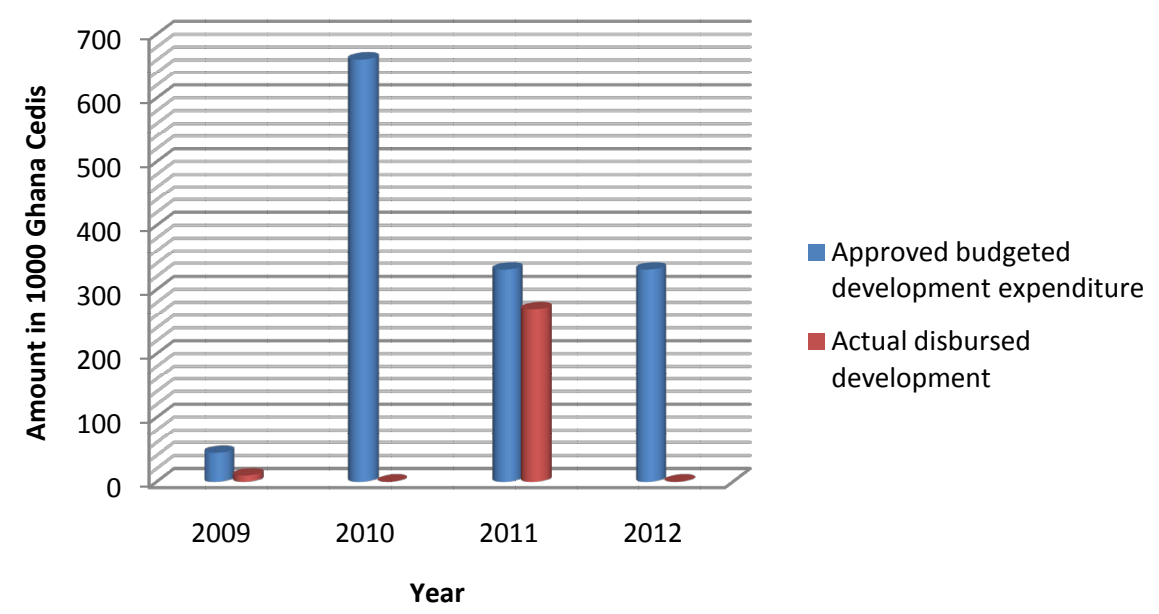

Figure 7. Government allocation to development. Source: Compiled by authors from ASTI/IFPRI-CORAF/WECARD-STEPRI survey data.

financial support. In all, apart from the salaries component of the budget, which does not show too much variation between the proposed, approved and disbursed funding, on the average CSIR has received only about 20 per cent of the approved budget for the period 2009-2012.

Non-government sources of funding are becoming increasingly significant in CSIR's operations. Given the continuing decrease in the recurrent component of the budget and the government's plans to wean scientific institutions such as CSIR off government funding, donor agencies are expected to play much greater roles in meeting Ghana's R\&D needs. However, further analysis of non-government source of funding for agriculture $R \& D$ is beyond the scope of this paper.

\subsection{Options for Policy Thrusts}

The study highlights a trend in increases in Ghana in the general public agricultural R\&D expenditure in 2005 Purchasing Power Parity (PPP) dollar from 2000 to 2011, which is quite appreciable. For CSIR, the pattern is not different with Agricultural R\&D expenditure increasing from 2000 to 2011. The trend also shows uneven pattern with peaks of 29.3 and 33.5 million (2005 PPP) dollars recorded in 2004 and 2009 respectively. This increase in spending over the period according to the underlying cost category breakdown reveals that different factors drove the growth. However, the increase does not necessarily demonstrate a resounding policy resolve for effective funding of agricultural R\&D such as which enhances knowledge infusion for growth-oriented and sustainable agriculture. The rapid increase in CSIR agricultural R\&D spending was driven mainly by the increase salary expenditure rather than expanded funding of research activities or greater investment in equipment or infrastructure. This is illustrated in the analysis of the funding trends in the three main categories of salary, operations and infrastructural development.

Government funds the bulk of agriculture R\&D budget at CSIR. Support from donors and development banks, proceeds from CSIR institutes' commercial activities and consultancies complement the government support. Generally there is always some difference in the approved and the actually disbursed budget to CSIR. On the average, the actually disbursed budget from government represents about 45 per cent presented to government for approval leaving a significant shortfall in funding. This shortfall mainly affects the operational and capital investment budgets which are critical in the operation of agricultural research in Ghana. The shortfall is normally taken up by non-governmental sources of funding such as donor and development banks, regional agencies, and domestic sources. These sources play a significant role in CSIR operations given the continuous decline of recurrent and capital investment component of the budget.

The volatility in the agricultural $R \& D$ spending is one of the indicators used in assessing the level of investments in agricultural R\&D across countries in the sub Saharan Africa (SSA). This indicator is drawn from a commonly used method of calculation price volatility in finance and output volatility in macroeconomics. Volatility analysis conducted on the agricultural R\&D spending at CSIR over the period 2000-2011 revealed some 
degree of volatility in R\&D spending from one year to the other with a volatility coefficient of 0.14 which signifies moderate volatility [26]-[28]. This therefore means that there is no constant inflow of funding over the period to support agricultural R\&D activities. This fluctuating pattern can be attributed to uneven investment into agricultural R\&D especially from donors and development banks that are important sources of funding for agricultural R\&D activities in Ghana and the decline in government support to actual agricultural R\&D activities. Again the agricultural research intensity ratio which is a measure of total agricultural R\&D spending as a percentage of agriculture output (AgGDP) was calculated for Ghana with an average of 0.62 . This is below the investment target of 1 per cent of agriculture GDP or more into agricultural research, which is indicative of the importance the government attaches to agricultural research in Ghana and therefore places emphasis on more sustained, reliable and regular funding from government in order to meet the overall goals enhanced productivity in the agricultural sector.

Currently the key policy consideration with respect to funding agricultural $R \& D$ is the government intention of weaning off CSIR of its public funding. Above all, the government has emphasized commercialization of CSIR as a whole as a result of which the R\&D resources from government is dwindling. While this goal is a laudable one and falls in tune with the establishment vision of the CSIR as expressed in Act 521 of 1996, the expectation of the government to achieve this in the very near future is unrealistic. In general less than 4 per cent of CSIR's total budgetary requirement is internally generated and increasing this to even 10 per cent in the next two years calls for some drastic measures. The goal of turning the CSIR into a financially independent agricultural R\&D institution needs to be carefully thought through.

\section{Conclusions and Policy Recommendations}

The study brought to the fore the need for a more strengthened and feasible commercialization policy for the public agricultural research institutes in Ghana. This has become necessary in order to get good returns on research innovations and technologies given out to farmers and the general public who are the main recipients of research outputs. These innovations and technologies are developed through lengthy and exacting Research and Development $(\mathrm{R} \& \mathrm{D})$ regime with both material and financial support from the government, donor agencies and development banks. But the challenge to this strategy of improving the internal commercialization policy is how to change the public perception of CSIR and the likes as public institutions offering public good for that matter, do not expect to commercialize research findings and technologies to be sold. Clearly, there is the need for the formulation of a strategy that will promote the aggressive propagation of all research output of CSIR for commercial gain.

It is also recommended that partnership with the private sector for the commercialization of the research outputs be vigorously pursued. As indicated, agriculture and agribusiness promises great wealth for Africa. Research establishments such as the CSIR have great potential in tapping into such wealth given that the knowledge base for more productive agriculture rests with these establishments. A strong orientation of the CSIR to business and market principles in its operations is very necessary. This however needs to balance carefully with the general principle of promoting agricultural technologies for achieving development goals such as poverty reduction and eradication of hunger, which are at the core of the SDGs.

The volatility in the agricultural R\&D spending trend can be attributed to donor and development banks support to agricultural research which turn to vary from one year to the other an indication of an irregular source of funding. This therefore affects planning of research regime which is mostly long term in nature. Donor support is generally short-term and ad hoc and this calls into question the long-term effectiveness and efficiency of this type of funding. It also indicates the unreliable nature of donor support to agricultural R\&D; another contributory factor to the volatility in the agricultural spending is the continuous decline in government budget for research activities in CSIR. It implies the need for a new policy direction which will ensure more sustainable sources of funding for agricultural research at CSIR. Again there is the need for coordination of donor support with national priorities. Establishment of national competitive funds for agricultural research will go a long way in addressing the challenge for a regular, reliable and sustainable funding for agricultural research in Ghana.

In the face of declining funding for agricultural R\&D, there is the need for a policy that will facilitate and guide close collaboration of CSIR with other agencies in the National Agriculture Research System (NARS) to pool resources to work on common research projects for national development to ensure effective use of resources. More importantly, government responsibility for funding agricultural R\&D must be emphasized. 


\section{References}

[1] DFID (2008) Sustainable Agriculture. Department for International Development. www.research4development.info/researchTopicWithNewsFeed.asp?topic=Sustainable\%20Agriculture

[2] Global Harvest Initiative (2011) Improving Agricultural Research Funding, Structure and Collaboration. http://www.globalharvestinitiative.org/index.php/policy-center/improving-agricultural-research-funding-structure-andcollaboration/

[3] The World Bank (2013) Unlocking the Potential of Agribusiness. The World Bank, Washington DC.

[4] FAO (2015) Regional Overview of Food Insecurity in Africa: Africa Food Security Prospects Brighter than Ever. Accra, FAO.

[5] FAO (2009) How to Feed the World in 2050. Food and Agriculture Organization. www.fao.org/3/a-ak542e/ak542e13.pdf

[6] Zorya, S., Morgan, N. and Rios, L.D. (2011) Missing Food: The Case of Post-Harvest Grain Losses in Sub-Saharan Africa. World Bank.

http://documents.worldbank.org/curated/en/2011/04/15808176/missing-food-case-postharvest-grain-losses-sub-saharan -africa

[7] NEPAD (2003) AU Assembly Declaration. Addis Ababa. New Partnership for Africa Development. www.nepad.org/system/files/Maputo Declarattion.pdf

[8] NDPC (2015) Ghana Shared Growth and Development Agenda (GSGDA) 2014-2017. National Development Planning Commission, Accra.

[9] ISSER (2015) The State of the Ghanaian Economy in 2014. Institute of Statistical Social and Economic Research, University of Ghana, Legon.

[10] Hawkins, B., Heemskert, W., Daane, R., Maatman, A. and Adekunle, A.A. (2009) Integrated Agriculture Research for Development (IAR4D). A Concept Paper for the Forum for Agriculture Research in Africa (FARA), Sub-Saharan Africa, Challenge Programme (SSA-CP) FARA, Accra.

[11] Alston, J., Pardey, G., Chan-Kang, T., Wyatt, J. and Marra, M. (2000) A Meta-Analysis of Rates of Return to Agriculture R\&D. Research Report No. 113, International Food Policy Research Institute (IFPRI), Washington DC.

[12] Meinzen-Dick, R., Adato, M., Haddad, L. and Hazell, P. (2004) Science and Poverty: An Interdisciplinary Assessment of the Impact of Agriculture Research. International Food Policy Research Institute (IFPRI), Washington DC.

[13] Seek, P.A. (2013) Repackaging Agricultural Research for Greater Impact on Agricultural Growth in Africa. Journal of Food Security, 1, 30-41.

[14] UNEP (2006) Our Planet. The Magazine of the United Nations Environment Special Edition. United Nation Environmental Program (UNEP), Kenya.

[15] Alene, A.D., Manyong, V.M., Abele, S. and Sanogo, D. (2006) Assessing the Impact of Agricultural Research on Rural Livelihoods: Achievements, Gaps, and Options Scientific. Papers Presented during the Twenty-Sixth Conference of the International Association of Agricultural Economists, Brisbane, 12-18 August 2006, 80 p.

[16] Alene, A.D. and Coulibaly, O. (2009) The Impact of Agricultural Research on Productivity and Poverty in Sub Saharan Africa. Food Policy, 34, 198-209. http://dx.doi.org/10.1016/j.foodpol.2008.10.014

[17] Benin, S. and Yu, B.X. (2012) Complying the Maputo Declaration Target: Trends in Public Agricultural Expenditures and Implications for Pursuit of Optimal Allocation of Public Agricultural Spending. ReSAKSS Annual Trends and Outlook Report 2012. http://resakss.org/sites/default/files/pdfs/ReSAKSS_AW_ATOR_2012_FINAL.pdf

[18] Pardey, P.G., Beintema, N., Dehmer, S. and Wood, S. (2006) Agricultural Research: A Growing Global Divide? http://ebrary.ifpri.org/utils/getfile/collection/p15738coll2/id/125246/filename/125247.pdf

[19] Scoones, I. (2005) Governing Technology Development in Africa Challenges for Agricultural Research in Africa. IDS Bulletin, 36, 109-114. http://dx.doi.org/10.1111/j.1759-5436.2005.tb00206.x

[20] Beintema, N.M. and Stads, G.J. (2011) African Agricultural R\&D in the New Millenium: Progress for Some, Challenges for Many. International Food Policy Research Institute (IFPRI), Washington DC.

[21] Government of Ghana (1996) Council for Scientific and Industrial Research Act, 1996, Act 521. Council for Scientific and Industrial Research, Accra.

[22] Rheenen, T., Obirih-Opareh, N., Essegbey, G., Kolavalli, S., Ferguson, J., Boadu, P., Fuseini, M. and Chiang, C. (2012) Ghana Strategy Support Program: Agricultural Research in Ghana. Working Paper 29, IFPRI, Washington.

[23] The World Bank (2013) World Development Indicators. http://databank.worldbank.org/data/reports.aspx?source=world-development-indicators 
[24] Awuni, S. and Essegbey, G.O. (2014) Developing an Enabling Scientific Equipment Policy in Africa: The Ghana Country Study. Science and Technology Policy Research Institute-CSIR, Accra.

[25] Essegbey, G.O. and Asare, R. (2014) Assessment of Agricultural Research Capacities in Ghana: The Case of Council for Scientific and Industrial Research (CSIR). http://ebrary.ifpri.org/cdm/ref/collection/p15738coll2/id/128689

[26] Guellec, D. and Ioannidis, E. (1997) Causes of Fluctuations in R\&D Expenditures: A Quantitative Analysis. Paris France. OECD Journal: Economics Studies No. 29, 1997/II.

[27] Durlauf, S.N., Johnson, J.A. and Temple, P.R.W. (2005) Growth Econometrics. In: Agion, P. and Durlauf, S.N., Eds., Handbook of Economic Growth, Elsevier, Amsterdam, 555-677.

[28] Stads, G.J. and Beintema, N. (2015) Agricultural R\&D Expenditure in Africa: Analysis of Growth and Volatility. European Journal of Development Research, 27, 391-406. http://dx.doi.org/10.1057/ejdr.2015.25 